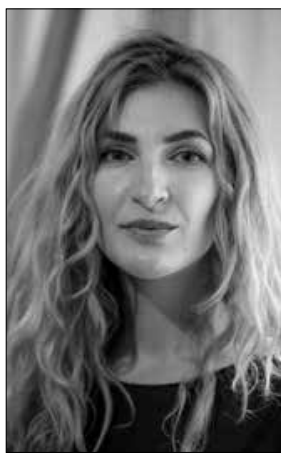

https://doi.org/10.24101/logos.2018.81

Gauta 20181026

LAURA VARNAUSKAITÉ

Vilniaus universitetas, Lietuva

Vilnius University, Lithuania

\title{
TEATRAS PO ANTROJO PASAULINIO KARO: LYGINAMOJI BECKETTO ABSURDO TEATRO IR BUTÕ AVANGARDO TEATRO ANALIZE்
}

Theater After the Second World War: Comparative Analysis of the Beckett Absurd Theater and the Butoh Avant-Garde Theater

\section{SUMMARY}

The purpose of this article is to reveal how the greatest conflict of the twentieth century has affected the human consciousness and how this change was manifested in the artistic form of expression - through language and body on the stage of the theater. Two examples in different civilizations have been chosen as the subject of the study: Samuel Beckett's absurd theater in the West and the Butoh avant-garde theater in Japan, which are compared on the basis of Vytautas Kavolis civilization analysis methodology. Within the chosen forms of theater as a way of artistic creation and social protest, one can try to trace the change of consciousness in the very civilizations. The question is, whether these forms of theatre signify a change of consciousness associated with moral and intellectual responsibility or whether it is an existential effort to perceive being in the wrong world or ir is mercy for those who have survived the war?

\section{SANTRAUKA}

Straipsnyje atskleidžiama, kaip didžiausias XX a. karinis konfliktas paveikè žmogaus sąmonę ir kaip šis pokytis buvo manifestuojamas menine raiškos forma - per kalbą ir kūną teatro scenose. Tyrimo objektu pasirinkti du pavyzdžiai skirtingose civilizacijose - Samuelio Becketto absurdo teatras Vakaruose bei butõ (anglų k. butoh) avangardo teatro kryptis Japonijoje, kurie lyginami remiantis Vytauto Kavolio civilizacijų analizès metodologija1. Straipsnyje parodoma, jog pasirinktose teatro kaip meninès kūrybos ir socialinio protesto raiškos formose galima aptikti sąmonės pokyti skirtingose civilizacijose. Klausiama, ar šios teatro formos žymi su moraline ir intelektualine atsakomybe susijusį sąmonės pokyti. O gal tai yra egzistencinės buvimo klaidingame pasaulyje suvokimo pastangos arba gailestingumas tiems, kurie išgyveno karą?

RAKTAŽODŽIAI: avangardas, absurdo teatras, Samuelis Beckettas, Tatsumi Hijikata, Kazuo Ohno, Vytautas Kavolis. KEY WORDS: avant-garde, absurd theater, Samuel Beckett, Tatsumi Hijikata, Kazuo Ohno, Vytautas Kavolis. 


\section{IŽANGA}

Po Antrojo pasaulinio karo Vakaruose susvyravo tikèjimas pažanga, ideologinèmis idejomis, Dievu, gyvenimo prasme. Žmogus turëjo surinkti išbarstytas prasmes, sudužusias viltis, atkurti pakrikusią sąmonę, tapatybę, vertybes ir tikejjimą. Egzistencialistai ieškojo atsakymų i esminius žmogaus būklès klausimus. Albertas Camus svarbiausiu filosofijos dalyku ivardijo klausima, ,ar gyvenimas vertas, kad ji gyventum, ar ne“ (Camus 1997: 9).

Japonijoje, kitaip nei Vakaruose, vyko branduolinis karas, kuriam nebuvo įmanoma pasipriešinti. Pralaimejjimas kare bei vakarietiškas Japonijos atstatymo planas sąlygojo „nacionalinio kūno” (koku- tai) subyrëjimą iš vidaus" (Calamoneri 2014: 33). Prarasta laisvè, sugriauti miestai, subjauroti gyvenimai skatino menininkus šią išorinès galios sukeltą itampą išlyginti priešinga jai kūrybine raiška per atsidavimą iracionalumui, bejejgiškumui, jausmingumui, mistiškumui, amorfiniam stiliui bei intensyviai eschatologinei refleksijai. Meninejje kūryboje buvo keliami gilios istorinès krizès, pralaimèjimo kare, ideologiju pabaigos bei žmogaus trapumo klausimai. Šiame kontekste klausiama: koki vaidmeni atlieka menas istorinių krizių laikotarpiu? Koks jo santykis su politine bei socialine sistema? Kaip menas keičia individo sąmonę?

\section{TEATRO KAIP MENO VAIDMUO VISUOMENĖJE}

Remiantis lyginamųjų civilizacijų ir meno sociologijos profesoriumi Vytautu Kavoliu, menas pagrịstai "gali būti laikomas generalizuota visuomenès sistema, skirta atlikti nenumatytoms ir neatpažintoms (tačiau, nepaisant to, reikalingoms) psichologinèms ir kultūrinèms funkcijoms" (Kavolis 2007: 156). Todèl galima kalbėti apie menininką kaip žmogiškosios sąmonès architekta, kuris dirba su paslèpta, bet ne mažiau svarbia, nei viešai demonstruojama, žmogiškosios egzistencijos puse.

Šiame kontekste teatras yra specifinè meno rūšis. Čia nèra išliekamumo momento. Tai, ką galima užfiksuoti žiūrovams stebint veiksma, išlieka tik ju prisiminimuose. Vaidmens atlikëjas ne tiek pakartoja išmoktus judesius ar žodžius, kiek perteikia îkūnytą charakterị ir są- monės būseną. Ši būsena kyla, viena vertus, iš atlikèjo ego nunykimo persikūnijant i kuriamą vaizdinį, antra vertus, iš santykio su auditorija, kai atlikëjas ir stebètojas tampa bendro energetinioprasminio lauko dalimi. Nagrinėdamas kūną savo veikale Sovokimo fenomenologija Merleau-Ponty teigia, jog „,̌̌velgti i objektą - tai jame apsigyventi“ (MerleauPonty 2008: 81). Šitaip stebintysis ikurdina savo mintis ir jausmus atlikejjo projektuojamame vaizdinyje ir igyja gebejjmą kartu su juo transformuoti savo buvusias patirtis ir jausmus i naujai kuriamas prasmes.

Kitas svarbus dalykas yra meno kaip socialinès kritikos funkcija. Ji yra aiškiau atpažìstama nei paslèptoji. Visais laikais menui vienas svarbiausių kūrybos šaltinių buvo tikejjimas ideologine ar politine 
sistema, kurios tobulumą ar sugedimą jis pasirinkdavo manifestuoti kūryboje. Tiesa, socialinè kritika nèra pagrindinè meno funkcija, tačiau gali įkvèpti pradèti esančią sistemą kritikuojantį meninį judèjimą. Šiame tekste pasirinktos teatro kryptys, kurios savo esme buvo totalitarinių režimu, žmogaus orumo nuvertinimo bei laisvès naikinimo kritika. Prie to bus sugrižta vèliau.

Taip pat galime daryti prielaidą jog menas didžiưjų krizių laikotarpiais atlieka religijos funkcija. Po karo religija patyrẻ stiprų išbandymą dèl negebejimo atsakyti i išgyvento žiaurumo ir dieviško teisingumo disonansą. Galima klausti, kas tuomet, kai religija praranda gebėjimą atsakyti į egzistencinius klausimus, kylančius žmogui po patirtų istorinių krizių, tampa jos atsvara? Tam reiškiniui paaiš- kinti Kavolis iškelia tezę, jog vykstant istorinei krizei, religija atlieka ar bando atlikti jos valdymo funkciją o grèsmei praejjus, pokrizinès integracijos vaidmuo pereina menui ${ }^{2}$. Todèl straipsnyje nagrinejjama, ar teatras, kaip meno forma, po karo koncentravosi i vientisumą praradusios sąmonès integravima, šitaip tapdamas pokrizines integracijos fenomenu.

Dar viena svarbi po krizès iškylanti meno funkcija - užpildyti emocini vakuu$m a$, atsiradusi dèl susvetimëjimo visuomeninei struktūrai, ir prasmès visame, kas vyksta, nematymo. Objektyvūs struktūriniai pokyčiai - pralaimètas karas bei didžiulès patirtos netektys - sukūrẻ emocinį vakuuma, kuriam užpildyti nebepakako buvusiu meno formų. Iš to kilo poreikis kurti kitoki meną ${ }^{3}$. Vakaruose juo tapo absurdo teatras.

\section{ABSURDO TEATRO PRASMINIAI KLODAI}

Absurdas (lot. absurdus - nedarnus, beprasmiškas; nelogiškas) mene pasirode $X X$ a. viduryje ir daugiausia paveike literatūrą bei teatrą. Visuomenẻ buvo supažindinta su nauju žanru, kuris prieštaravo ipprastai logikai: "Jei gera pjesė turi protingai sudarytą îstorija tai šie [draminiai kūriniai] neturi jokios istorijos arba siužeto" (Esslin 1961: XVII), nèra nei atpažizstamų charakterių, nei jų aiškios motyvacijos, nèra nei pradžios, nei pabaigos, vietoje sąmojingo dialogo vapëjimas, kalbëjimas klišèmis, pasikartojimais. Absurdo teatro kūrinių temos totalitarinė sistema ir ribotos žmogaus galimybės reaguoti i ją, vienatvè, bejègiškumas, beprasmybès jausmas. Žmogus atkirstas nuo transcendentiniu šak- nų, patiria idealų, tikslų devalvaciją praranda gebèjimą priešintis kitu žmoniu ir sistemos kuriamam absurdui, o jo mintys ir veiksmai - beverčiai. Nepaisant, atrodytu, beviltiškos žmogiškos būklès, teatro kritiko Martino Esslino teigimu, absurdo dramos tikslas nèra absurdo teigimas, tačiau „galimybè pažvelgti $\mathfrak{i}$ absurdiškas situacijas atmerktomis akimis ir, patyrus katarsi, išsilaisvinti“ iš jo (Esslin 1961: 269).

Absurdo dramoje fiksuojamas emocijų bei sąmonès, viena vertus, ir veiksmu, tikslų, motyvu, supratimo atitrūkimas, kita vertus, sudarantys bendraji sociopsichologini modeli, kuri Kavolis įvardija psichologine esmès praradimo ir atotrūkio būsena: „„̌̌mogaus atitrūkimas nuo 
istorijos, nuo kitų žmonių, nuo kalbos, emocijos atsiejimas nuo prasmės, veiksmo nuo tikslo, nuo padarinių ir nuo "savęs paties" <...> bei substancijų išgaravimas (kur tiek veiksmas, tiek atoveiksmis tampa negalimas)" (Kavolis 1995: 139).

Šios dimensijos aiškiai juntamos Samuelio Becketto ${ }^{4}$ absurdo dramose. Vakaru pasaulyje jis laikomas absurdo teatro klasiku ${ }^{5}$. Toki titulą Beckettui pelnè pjesè „Belaukiant Godo”. Joje Estragonas ir Vladimiras laukia Godo, kuris vis nepasirodo. Laukimas lygu gyvenimui. Nuo Godo priklauso jų ateitis. Pjesèje gausu absurdo teatrui būdingu požymių $\left.^{6}: 1\right)$ ištrèmimas iš istorijos, kurioje ivykiai nebėra suvokiami kaip prasmingi ar emociškai reikšmingi: „ESTRAGONAS. Atsimeni ta diena, kai puoliau $i$ Diuransos upe? VLADIMIRAS. Tada skynem vynuoges. ESTRAGONAS. Tu mane ištraukei. VLADIMIRAS. Viskas jau užmiršta ir palaidota“; 2) psichologiškai „maitinančių" ir patenkinančių santykių negalimybè: "Aš irgi dejausi, kad ju nepažistu. O be to, mūsu niekas niekados nepažins"; 3) veiksmų nuvertinimas, kai veikti privaloma imituojant gyvenimą: „Vis prasimanom $\mathrm{kg}$ nors tokio, kad apdumtume akis ir itikintume save, jog dar tebegyvenam <...>"; 4) laiko suvokimo praradimas: „Ar jūs nesiliausi- te kvaršinę man galvos su savo pasakom apie laika! <...> viena diena, tokia pat kaip ir kitos, jis tapo nebylys, viena diena aš apakau, viena diena mes apkursime, viena diena mes gimeme, viena diena mes mirsime, <...> ar to jums negana? <...> Jos pagimdo, apsižergusios kapa, akimirka nušvinta diena, paskui vèl naktis"; 5) veiksmų ir mąstymo neefektyvumas: „VLADIMIRAS. O čia ne pati didžiausia beda, iš tikruju. ESTRAGONAS. Kas? VLADIMIRAS. Kad mes galvojom. ESTRAGONAS. Savaime aišku. VLADIMIRAS. Bütume galeje apsieiti ir be to. ESTRAGONAS. Ka beveiksi“; 6) pasyvumas jaučiant, kad veikia aplinkybès ir atsitiktinumai: „POCO. Aš niekaip negaliu <...> išeiti. ESTRAGONAS. Toks gyvenimas"; 7) nesugebejjimas suprasti krypties ir vidiniu motyvų: „VLADIMIRAS. Kur dabar einate? POCO. Man tas nerūpi"; 8) bendras beviltiškumo jausmas: „ESTRAGONAS. Būtu neblogai, jei mane užmuštu kaip ana, kita. VLADIMIRAS. Kuri kita? <...> ESTRAGONAS. Kaip milijardus kitu“; 9) gyvenimas iliuzijoje vengiant įsisąmoninti realią žmogaus būklę: „Ore skamba mūsu verksmai. <..> Bet iprotis - didysis marintojas ${ }^{\prime 7}$ (Beckett 2009: 46-86). Čia blykstelejusi sąmonès šviesa užtemdoma laukimo rutina $^{8}$, šitaip apsisaugant nuo skausmingo apgailètinos žmogaus būklès suvokimo.

\section{AVANGARDO KULTÜRA JAPONIJOJE: KŪNAS KAIP UŽUOJAUTA IR PROTESTAS}

Japonijoje po Antrojo pasaulinio karo ìvykęs sąmonès lūžis, virtęs nauja meno forma, susijęs su individualios ir kolektyvinès sąmonès santykio peržiūra. Po karo, subyrèjus Japonijos „nacionaliniam kūnui“", buvo peržiūrimas santykis tarp individo ir didesnès kolektyvinès visumos, tarp žmogaus kūno ir tautos kūno. Tyrinètojai pažymi, jog ivyko „didžiulis kūno koncepcijų poslinkis šeštajame ir septintajame dešimtmečiais Japonijoje priešinant nikutai [kūnas (flesh), kūniškas / 
jausmingas] ir kokutai [nacionalinis kūnas] kultūrines reprezentacijas" (Calamoneri 2014: 35). Ieškota meninès raiškos formu, kurios manifestuotų individualų kūną.

Butõ kilo iš „pogrindinio“ judèjimo9. Jo pradininką įkvejpè su gamta susiliejantis ir energetinius srautus valdantis kūnas vokiečių ekspresionistiniame šokyje Ausdrucktanz, taip pat prancūzu siurrealistu judejimas ${ }^{10}$, filosofas ir rašytojas Marquisas de Sade'as, poetas Isidore'as Lucienas Ducasse'as. Ankoku Butõ kaip visų egzistuojančių šokio ir teatro stiliu Japonijoje paneigimas tapo avangardine menine kultūra ${ }^{11}$. Galima klausti, kaip butõ atspindi avangardinès kultūros bruožus? Pagrindiniai jų: 1) principinio susvetimejjimo reikšmingiems egzistuojančios tikrovès elementams pojūtis, 2) sąmoningas įsipareigojimas iveikti egzistuojančios tikrovès trūkumus naujo pobūdžio meninèmis priemonèmis (plg. Kavolis 2007: 175) bei 3) siekis iš tuštumos save sukurti savo paties pastangomis (Kavolis 1995: 129).

Butõ meno funkcija, kaip ją matè kūrẻjas, - išreikšti žmogaus laikyseną krizės situacijoje, taip pat suprasti kita, jo trapumą ir negalią. Hijikata žodžiais: „Per šoki mes turime vaizduoti žmogaus laikyseną krizèje <...>. Kai aš pradejjau norèti būti suluošintas, nors buvau visiškai sveikas, <...> tai buvo pirmas žingsnis i priekị link butõ " (Hijikata, cit. iš Crump 2006: 61). Juliette T. Crump ${ }^{12}$ nebyliojo teatro šerdi surado vienoje esminiu budistiniu vertybiu - galingą ekspresiją ikvepiančioje užuojautoje (compassion). Žengimas i prieki „,suluošintomis“ kojomis krizès akivaizdoje yra vienybės ir užuojautos ženklas. Kaip deivè Kannon ${ }^{13}$ siekia sumažinti kančias pasaulyje, taip ir butõ atmeta žmogų supančią kančia, pokarinès industrinès fragmentacijos ir chaoso persmelktą aplinką. Butõ atlikèjas „sukuria ryší su savo prarastomis dalimis, su prarastu esmių (lost beings) pasauliu" (Crump 2006: 63) ir apglèbia tuos, kurie yra trapūs, pažeidžiami, atsidūrę visuomenès paribiuose.

Butõ teatre meninès išraiškos būdai nepakluso jokiai logikai ar racionalumui. Vienas pradininkų Kazuo Ohno ${ }^{14}$ kūrinyje „Negyva Jūra“ („The Dead Sea“) pavaizdavo rūką. Autoriui atrodè, jog nelogiški sprendimai išlaisvina. Šitaip menininkai laisvinosi iš vakarietiškų modernybės standartu ir pradejjo kurti alternatyvią modernybei sąmonę, susiejančią gamta, mitologija, teatrą ir šokị. Čia susipina keletas avangardinès kultūros požymių: įsipareigojimas įveikti egzistuojančios tikrovės trūkumus naujo pobūdžio - nelogiškomis - meninèmis priemonèmis, taip pat siekis iš tuštumos - šiuo atveju rūko - save sukurti savo paties pastangomis.

Kalbant apie protesto formas, po karo japonų rašytojai stangèsi apsaugoti kūną nuo kviečiančios pasiaukoti propagandos, paskatinusios japonu pilotus kare aukoti savo gyvybes ịsirèžiant $\mathfrak{i}$ priešininku pilotuojamus naikintuvus. Politinè kritika buvo susijusi ir su vulgariomis erotinėmis priemonėmis. Kūrybos pradžioje tai buvo būdinga ir butõ, kada pasirodymuose kūnas iš suluošinto tapdavo gašlus, ir atvirkščiai. Šitaip kūnas mene buvo naudojamas priešinantis hegemonijai kaip žmogiško kūno ir jo troškimų subordinavimo ir pavergimo nacionaliniam kūnui priemonei. 
Hijikata eksperimentavo su ekstazès patirtimis, per ekstremalu skausmą ir pasiaukojimą gana sąmoningai naudodamasis vakarietiško avangardo literatūra ir vizualiaisiais menais (pgl. Clamoneri 2014: 36). Griežtai pasisakè prieš parodomąji šoki, pasiaukojimas turejo tapti kiekvieno šokèjo dalimi. Šitaip atsirado nauja kūno architektūra, kurioje svarbu ne judesiai, choreografija bei virtuoziškumas, bet gyvas kūnas kaip patirties ir transformacijos vieta. Pasiaukojimas nelygu bejègiškai „aukos sąmonei“, kuriai Hijikata priešstatè „pirmines patirtis": nuogas karys nuogoje gamtoje. Savo esè Pavydint šuns venu (From Being Jealous of a Dog's Vein) (1969) Hijikata užbaigia žodžiais: „Noriu tapti ir būti kūnu tiesiog su plačiai atmerktomis akimis, itemptomis iki lūžio taško per i̇sirèžusi santyki su kilniu (dignify) kraštovaizdžiu aplink jï“ (Hijikata, cit. iš Clamoneri 2014: 36), šitaip išreikšdamas gryną santyki su gamta per autentišką patirti ${ }^{15}$.

Butõ vaizdinio kūrimui ir atlikimui didelę reikšmę turi kasimasis gilyn, tarsi svogūno lukšto lupimas. Per išgyventos istorijos patyrimą siekiama atverti gilesnius kūno sluoksnius: „kiekvienas turi kasinèti savo kūną <...> vieną po kito nusirengdamas savo paties sluoksnius tam, kad prasiskverbtų i psichikos gel- mes" (Waychoff 2009: 45). Tačiau per didelè koncentracija i minti ar techniką sukelia pavojų prarasti gyvybę, kuri yra natūrali, kūniška. Tam, kad atlikèjas užmirštų technika, žodžius ir pasiduotų gaivališkai emocijai, jis prieš tai turi juos pažinti. Šitaip judesių technika ir mintis subordinuojama kūnui leidžiant gyvybei nevaržomai skleistis. Tai yra suartëjimas su dzenbudistine praktika, kai šokèjas save visiškai ištuština tam, kad leistu kuriamam vaizdiniui skleistis per save. Kazuo Ohno žodžiais: „Aš šokau Gyvenimą ir Gyvenimas mokè mane. Todèl aš tiesiog sekiau Gyvenimą..."

Viena dzenbudizmo tiesų sako: „Kai sugrižtame prie šaknu, mes igyjame prasmę (meaning)“ (Suzuki 1960: 78). İdomu pažymèti, jog Beckettui „„̌̌aknimis“ prasmès, paguodos ir ramybės uostu, kai nieko nelieka, arba nėra kuo tikèti, tampa "motinos iscčios“: "Dar yra, aišku, mano pasakojimas, kai jau nieko kito nebelieka. <...> Ilgas gyvenimas. <...> Prasideda issčiose, kur kitados prasidedavo gyvybe, Mildreda <...> prieš mirdama <...> prisimins motinos įsčias" (Beckett 2009: 163 („Laimingos dienos”)); arba pasinèrimas visa esatimi i bundančios gyvybės dvelksmą: ">...> štai ji vélei lauke... balandžio rytas... veidas skendi žolejj... nieko aplink... tik vieversiai... ir ten mégina pradèti iš naujo..." (Beckett 2009: 295 (,Ne aš”)).

\section{KŪNIŠKA VERSUS TEKSTUALI TEATRO KALBA}

Viena pagrindinių temų, atveriančių plačius komparatyvistinius horizontus Rytų ir Vakarų teatro formose, yra kalbos vartojimas - nuo beprasmio žodžių pertekliaus iki visiškos tylos ir tuštumos.
Avangardiniame japonų šokio teatre nèra žodžiú, čia kalba kūnas. Kaip teigia Sakurako San ${ }^{16}$, „kūnas nemeluoja“. Žodžiai yra proto konstruktas, o kūnas yra arčiau tiesos - jis byloja tiesiogiai apeidamas in- 
telektą, šablonus, klišes, ivardijimus, ivaizdžius. Žvilgsnis, aprepiantis visą aplinka, fiksuotas ị horizonta, esantis giliausias sąmonès, jausmų ir sielos atspindys, pasakoja istoriją tikriau ir giliau, nei tai daro žodžiai. Žmogus - tai kaleidoskopas, saugantis kūne įvairius vaizdinius, kurie atgyja lyg ryškinant nuotraukos negatyvą: teka upe, kyla ugnikalnio lava, sklaidosi tarsi rūkas, trupa lyg rūdys. Kūne, raumenyse ir kauluose įrašyta atmintis, kurią sužadinti galima juose apsigyvenus. Kiek trunka vyksmas, tiek trunka atlikejjo bei stebètojo persikèlimas i kitą laiką, erdvę, sąmonę. Tai transformacijos vyksmas, leidžiantis susidurti su prisiminimų, projekcijų ar jausmų spaudimu ir perkeisti juos.

Butõ atlikimas - tai vidinè transformacija per ",atsivèrusį" lyg žaizda kūną. Tam, kad ši transformacija galètų vykti, atlikèjas turi nusirengti savo ego, ištuštinti save visiškai, kad taptų irankiu naujoms prasmėms kurti. I tranformaciją iveda išgyvenimo prisiminimas: sąstingis, puvimas, gimimas ir mirtis - visa tamsioji sąmonės pusè, stebėtoją sukrečianti lyg mirtis, į kurios šiurpą bijoma žiūrèti, bet ir negalima nuo to pabègti. Tas viliojantis mirties ir atgimimo slèpinys sukuria terpę, kurioje menininkas tampa archeologu, pamažu valančiu žemes, rūdis, pelèsi nuo žmogaus sąmonès, šitaip sudarydamas galimybę kurti save iš naujo. Todèl butõ nuogas ir grynas, šokiruojantis - kupinas traukulių, drebulio, nebylaus šauksmo, nustèrusių akių, surakintų kaulų, išsukinėtų riešų ir pirštų - patenka į uždraustą, ištrinta, palaidotą sąmonès ertmę, kuri vyksmo metu gali būti transformuota. Toji estetiškai šiurpi atlikèjo būklè, kitaip nei tradiciname japonų ar vakarietiškame absurdo teatre, niekada nèra naivi ar plokščia, bet ì gyli orientuota žmogaus sąmonès dimensija.

Kyla klausimas, kuri kadaise kèlè Beckettas diskusijose su Jamesu Joyce'u: ar kalba dar gali būti metafizinès tiesos perdavejja? Ar autorius gali kastis giliau, i nenusakomas žmogaus patirtis - „nerimo gręžinius" - ir tuos giliuosius užspaustus išgyvenimus perteikti taip, kad neužmaskuotų jų žodžiais lyg užmaršties piliulèmis pasąmonejje?

Nors airių kilmès dramaturgas buvo ìsitikinęs, kad žodžiai neperteikia prasmès, vis dèlto žodžiai yra tai, kas mums duota: "Que voulez-vous, Monsieur? C'est les mots. On n'a rien d'autre ${ }^{\prime 17}$, - sako Beckettas. Jo pjesėse daug žodžių ir daug kūno, kurie, atrodytų, neturi jokios prasmès, savotiška kalbos ir kūno devalvacija. Veikèju kūnai ir kalba yra nuolat aktualizuojami ir nuolatos esti kraštutinès būklès: arba fiziškai neigalūs, arba pertekliškai kūniški, arba bekalbiai, arba nesulaikomas žodžių srautas. Pjesėje „NNe aš” moteris išreiškia ribinę situaciją tarp visiško nebylumo ir nekontroliuojamo žodžių srauto, tarp fizinio nejautrumo ir pojūčių antplūdžio: "> ...> visas kūnas tarsi pranyko... tik lūpos... skruostai... žandai... liežuvis... nenurimstąs né sekundei... deganti burna... žodžiu srovė... ausyse... faktiškai ausyse... né pusés nesuprantant... ne ketvirtadalio... ka ji sako..." (Beckett 2009: 292). Veikèju kalba yra jų pačių nekontroliuojama, nerišli, išskaidyta. „Paskutinèje Krepo juostoje" naudojama mašina, kurios pagalba kalba suskaldoma sugrižztant ì praejjusį laiką. Arba pjesėje „Ne aš” veikia nepažini išorinè jèga, neleidžianti prabilti: ", „..> o gal... tai mechanizmas... 
panašiau i mechanizma... tokị išderintą... kad niekas jos nepasiekdavo... arba ji negalédavo atsakyti... buvo kaip suparalyžiuota..." (ten pat: 291). Čia negalèjimas kalbèti gretinamas su kūno negalia. Arba pjesèje „Laimingos dienos" kalbą suskaido mechaninès kliūtys, patiriamos dèl bandomo išskleisti skèčio: "Žmogus vis atidelioji - ji iškelti - nes bijai iškelti - per anksti - ir diena sau slenka - visa praslenka - o žmogus taip jo ir neiškèlei - visiškai neiškèlei" (ten pat: 152). Anapus žodžiu šiame epizode galima atpažinti žmogaus bejègiškuma, praradimą gyvenimo prasmès ir krypties, kuriuos bandoma atkurti vis griebiantis kokio daikto: skèčio, šukų, veidrodžio, krepšio: „Protas sako man, nuleisk $j i$, Vini, jis tau nieko negelbsti, pasidek ji ir stverkis ko nors kito" (ten pat).

Kūnas čia yra svarbi semantinè figūra, prasmès teikèjas. Iki krūtinès užkastai moteriai sakoma: "Iškasti ja <...> reikia, šitokia ji neturi jokios prasmés" (Beckett 2009: 156). Nejudrus kūnas yra svetimo pasaulio, kuris sustingdo žmogaus jausmus, išraiška: "Ne, kažkas turi atsitikti, kažkas turi pasaulyje joykti, kokia nors permaina, aš nebepajëgsiu, jei reikès vèl judeti." (ten pat: 152). Šiame svetimame pasaulyje žmonès susitinka su savo negalèmis ir, patirdami stygių, yra arčiau vienas kito, jie gali suprasti ir priimti kito negalią: "Na ka gi, aš tavęs nekaltinu, ne, nepritiktu man, negalinčiai pajudèti, barti savo Vili, kad jis negali kalbèti“ (ten pat: 153).

Autorius naudojosi žmonių kūnais, daiktais bei skyrybos ženklais siekdamas perteikti tai, kas negali būti išsakyta žodžiais. Skyrybos ženklų nebuvimas dialoguose, pakartojimai ir klišès, bekalbè burna, zvimbimas ausyse, veikejjo susigūžimas issčiose esančio kūdikio poza, rankų pakėlimas ị šalis kaip beviltiškas užuojautos gestas - visa tai rodo komunikacijos negalimybę. Virvė skirta pasikarti, rimbas tarnui valdyti ir t. t. yra pripažinimas iliuzijų dèl gatavų receptų, dèl problemų sprendimų ir sufabrikuotuc prasmių, kurios nieko negali pasakyti apie žmogaus pasimetimą krizès situacijoje, jo patiriamą kančią ir nevilti. Atsakydamas i šiuos iššūkius, Beckettas kuria anapus žinojimo esanačia samone, kuri, susidūrusi su žmogaus būklès siaubu, tampa nelogiška, absurdiška, naivi, depresyvi, suicidiška, bet, perëjusi per tai, leidžia patirti katarsi ir ji užliejančią tikrają ramybę: "Ramybè, taip, manau, štai tokia ramybe, o ta kančia... tarsi niekad jos nebūtu buvę“ (Beckett 2009: 279) („Komedija")). Paradoksalu, tačiau nieko tikro šis laikmetis negali pasiūlyti. Ramybè pasirodo besanti dar viena iliuzija. Kaip ir gailestingumas?

Pjesèje „Ne aš” Gailestingu Dievu tikèti išmokoma dar vaikystëje tam, kad būtų itteisintas nuodèmès ir bausmès mechanizmas: "<...> tokiu atveju, žinoma... ta mintis apie bausmę... už ta nuodemę ar kita... ar už visas kartu... arba tiesiog šiaip be priežasties... šiaip, bausmé dèl bausmés... ji tuo nesistebejo... <...> kartu su kitais benamiais vaikais... ji buvo išmokyta tiketi... gailestingu (trumpai nusijuokia)... Dievu (smagiai juokiasi)“ (Beckett 2009: 290). Čia gailestingumas ir bausmė yra nuolatiniai pakrikusios sielos ir apskritai žmogaus, esančio krizės akivaizdoje, palydovai. Galima klausti, galbūt neišvengiamai po karo gailestingumas bet kurioje civilizacijoje tampa būdinga kūrybinès raiškos dalimi, nepriklausomai nuo meninio stiliaus ir kūrèjo sumanymo: liudyti ar keisti tikrovę? 


\section{APIBENDRINIMAI}

Siekiant palyginti individo sąmonès struktūru pokyčius po Antrojo pasaulinio per butõ ir absurdo dramos formas Rytuose ir Vakaruose, atsižvelgiama i nagrinètus prasminius klodus: avangardo ir absurdo teatro žymenys, teatras kaip socialinio protesto forma, kūno ir kalbos reikšmè kuriant ir perduodant prasmę, scena kaip sąmonès tranformacijos vieta, o menininkas - sąmonès architektas, individualios sąmonès arba kūno ir kolektyvinès sąmonès santykis.

Teatras Japonijoje bei Vakaruose po didžiosios žmonijos krizès atmetè pramoginio meno vaidmeni ir tapo transformacijos erdve. Tiek absurdo, tiek avangardo teatrui būdinga: judesių technikos, normalios kūrinio plètotés logikos ir bet kokios rutinizacijos atmetimas. Nelogiškos veikejju mintys ir veiksmai Vakaru abdurdo dramoje susipina su nelogiškais, stichiškais kūno judesiais japonų avangardo teatre. Butõ laikas cikliškas, apima gyvenimą ir mirti. Becketto teatras priarteja prie šios dimensijos paversdamas linijinį laiką cikliniu - nuolatiniu bandymu kartoti gyvenimą. Šitaip absurdo dramoje sąmone iš progresyvios tampa gamtiška, cikliška.

Lingvistinis dèmuo yra svarbi Becketto pjesių dalis, tačiau kartu pripažizstama, jog žodžiai nebegali perteikti prasmès. Tai yra absurdo teatro priartëjimas prie butõ, kuriame žodžiai beverčiai, o kūnas perduoda patirti be intelekto isikišimo. Tačiau, kitaip nei butõ, absurdo teatre prasmés ieškoma ne atsisakant žodžiu, bet $u$ ž išsakytu žodžiu, per simbolius: gesta, garsa, laika, erdvę.

Nuogas ar suluošintas kūnas butõ šokio teatre yra tylus protestas prieš esa- mą sistemą. Atitinkamai absurdo teatre naudojama nuosaiki protesto forma per radikalizuojančius realybę žodžius. Todèl, pritariant Kavoliui, galima teigti, kad kuo didesnis pavojus žmogui bet kur pasaulyje atsiduoti totalitarinei iliuzijai, tuo didesnis tarp menininku formuojasi poreikis sukrėsti žmogu pasirinktomis meninėmis priemonėmis.

Teatras, kaip meno forma, po karo koncentravosi į vientisumą praradusios sąmonès integravimą šitaip pakeisdamas religiją ir tapdamas pokrizines integracijos fenomenu. O menininkas - samonés integravimo architektu. Vis dèlto dèmesys skiriamas ne tiek kolektyvinei sąmonei - japonu kokutai, bet individualiai sąmonei ir jos integravimui.

Teatre išreiškiamos patirtys yra tranformuojamos per intencionalią sąmonę. Stebintysis vyksma, nesvarbu, ar tai būtụ Becketto pjesè, ar butõ, tarsi Jameso Joyce'o Uliso skaitytojas, pasineria į kito žmogaus sąmonę. Čia esti dvi galimybès - nepatikliai užsidaryti savyje ir nieko nepatirti arba surizikuoti atsiverti ir inerti i misterija - Dievo ar Kannon gailestinguma, iliuzijų demaskavima, baimių epifaniją bei pergalëjimą - ir grižti i save perkeista sąmone.

Galima teigti, jog Japonija po karo iš tyliosios tapo "šokančia“, iš nuosaikiai vesternizaciją priimančios - save iš savo pačios šaknų kuriančia civilizacija, o Becketto pjesėse kuriama anapus žinojimo esanti sąmoné tebèra temdoma vakarietišku pažangos šešèlių, todèl siekiančio atkurti prarastą ryši su gamta ir prigimtimi žmogaus žvilgsnis - lyg po nakties išsiilgęs saulès - vis krypsta i Rytus. 


\section{Literatūra}

1. Beckett Samuel. 2009. Teatras: dramu rinkinys. Vilnius: Baltų lankų leidyba.

2. Calamoneri Tanya. 2014. "Bodies in Times of War: A Comparison of Hijikata Tatsumi and Mary Wigman's Use of Dance as Political Statement". Congress on Research in Dance, doi: 10.1017/cor.2014.5, p. 32-38.

3. Camus Albert. 1997. Sizifo mitas. Vilnius: Baltos lankos.

4. Crump T. Juliette. 2006. „One Who Hears Their Cries": The Buddhist Ethic of Compassion in Japanese Butoh. Dance Research Journal, Vol. 38, No. 1/2: 61-73.

5. Esslin Martin. 1961. The Theatre of the Absurd. New York: Anchor Books.

6. Goodman D. G. 2017 [1988]. Japanese Drama and Culture in the 1960s: The Return of the Gods. Routledge: New York.

7. Goodman D. G. 2006. Angura Japan's Nostalgic Avant-Garde. Not the Other Avant-Garde: the Transnational Foundations of Avant-Garde Performance. Ed. James M. Harding and John Rouse: 250-264. Ann Arbor: U of Michigan.

\section{Nuorodos}

1 „Ėmusis tarpcivilizacinių palyginimų būtų metodologiškai pageidautina kelti klausima, kas vienoje tradicijoje yra išskirtina kitos tradicijos požiūriu, o po to visiškai apsukti perspektyvą, "svetimą“ tyrimų objektą paverčiant „sava“ klausinèjančiojo pozicija“ (Kavolis 1998: 251). Tuo būdu aptikus tam tikrą požymi japonų teatre butõ, to paties ieškoma ir Becketto kūriniuose.

2 „Visuomeninis domëjimasis menais yra linkęs mažèti, o domèjimasis religija - didèti per gyvybei pavojingas istorines krizes $<\ldots$. . Domejjimasis menais dažnai sustiprèja tokiems periodams pasibaigus. Religija yra labiau krizès valdymo, o menas - pokrizinès integracijos fenomenas" [Vertimas redaguotas L. Varnauskaitės] (Kavolis 2008: 145).

${ }^{3}$ Kavolio teigimu, ,[p]alankios salygos meninei kūrybai susidaro tada, kai spartūs visuomenès organizacijos ir jos individu emociju pokyčiai sukelia aštriai jaučiamą skirtumą tarp asmeninių emocijų ir objektyvios socialinès struktūros" (Kavolis 2007: 162).
8. Jevsejevas Andrius. 2009. Absurdo poetika Vidurio ir Rytu Europos dramaturgijoje. Literatūra ir menas 21 [3238]: 19.

9. Kavolis Vytautas. 1995 [1970]. Socialinè avangardinių kultūrų psichologija. Kultūrinè psichologija: 128-153. Vilnius: Baltos lankos.

10. Kavolis Vytautas. 1998. Civilizaciju analizé. Vilnius: Baltos lankos.

11. Kavolis Vytautas. 2007 [1974]. Meno sociologija. Socialiniai ir ekonominiai menu aspektai. I. Baltos lankos 27: 152-198.

12. Kavolis Vytautas. 2008 [1974]. Meno sociologija. Socialiniai ir ekonominiai menų aspektai. II. Baltos lankos 28: 137-170.

13. Merleau-Ponty M. 2008 [1945]. Suvokimo fenomenologija. I dalis. Kūnas. Baltos lankos 28: 79-105.

14. Suzuki D. T. 1960. Manual of Zen Buddhism. New York: Grove Press.

15. Waychoff Brianne. 2009. Butoh, bodies, and being. Kaleidoscope, Vol. 8: 43-53.

${ }^{4}$ Beckettas dar Dubline igijo platu meninį-humanitarinị išsilavinimą. Studijavo literatūra, filosofija, prancūzų kalbą, domëjosi teatru. Baigęs studijas ir išvykęs ị Prancūziją 24-erių gavo literatūrinį apdovanojimą už pjesę Whoroscope. Joje jaunasis Samuelis nagrinèjo Dekarto apmąstymus apie laika, vištos kiaušinius ir gyvenimo laikinumą (evanescence). Nors Beckettas laikè rutiną laiko vėžiu, semantinis pakartojimas (semantic repetition) vèliau tapo jo pjesiu darybos metodu.

${ }^{5}$ Svarbu pabrěžti, jog Beckettas nebuvo absurdo teatro kūrejjas. Absurdo teatro debiutu laikomas Kafkos „Proceso“ pastatymas 1947 m. Prancūzijoje, aplenkęs ir E. Ionesco „Plikagalvè dainininkè („La Cantatrice chauve“), ir S. Becketto „Belaukiant Godo“. Kafkos „Procese“ „žmogus yra teisiamas nežinia už ka, jis tèra mažytis didelès mašinos varžtelis, o kai jo nebereikia, milžiniškas biurokratinis aparatas jo lengvai atsikrato" (Jevsejevas 2009: 19).

${ }^{6}$ Pateikiama adaptuota Vytauto Kavolio absurdo teatro psichologinių požymių klasifikacija (žr. 
Kavolis, „Socialinè avangardinių kultūrų psichologija“, 1995).

7 Vertimas redaguotas L. Varnauskaitès (toliau L. V.).

8 Beckettui visas gyvenimas yra rutina, kurią retsykiais pakeičia „būties kančia“.

9 Reikia paminèti, jog šeštajame dešimtmetyje Japonijos teatras patyrẻ esminiu pokyčiu, siejamu su angura - „pogrindiniu“ judejimu. Tapukariu iškilęs naujasis shingeki teatras ilgainiui tapo funkcionieriška institucija, su psichologinio ir socialistinio realizmo elementais, prarado gebèjimą abejoti, transcenduoti. Nepasitenkinimas naujuoju teatru virto post-shingeki judejjimu. Chrestomatinis judèjimo kūrinys „Vulkaniniu pelenu žemè" („Land of Volcanic Ash"), pasirodęs antrąji kartą po trisdešimties metu 1961 m., kritiku pavadintas „paminklas nesèkmei“ , "nurodant ị marksizmo nesėkmę ir i proletarinį literatūrinį judèjimą, iš kurio kilo spektaklis" (Goodman 2018: 10). Kita pogrindinio teatro kryptis - Osanai shingeki tradicinio ir šiuolaikinio teatro hibridas, kuris rèmèsi europietišku ekspresionizmu kaip būdu atgaivinti tradicini ikimodernu teatrą Japonijoje, nesusiliejant visiškai su Kabuki (Goodman 2006: 253-254).

10 Šio pranešimo kontekste reikia priminti, jog siurrealizmas kilo iš dadaizmo judèjimo Pirmojo pasaulinio karo metais. Vieną pagrindiniu dadaizmo idèjų, jog žmogaus pasąmonė gali būti įkvèpimo šaltinis, tęsè ir radikalizavo siurrealistų judejimas. Siurrealizmo pradininkas Andre Bretonas savo Siurrealizmo manifeste iškè- lè "sąmonès cenzūros įveikos" ir "psichinio automatizmo" (ši pasiskolinta iš S. Freudo) idèjas. Šitaip nekontroliuojami proveržiai ir sąmonès srautas, sapnai ir vizijos kaip laisvos kūrybos skatuliai tapo "nesąmoningo" meno varikliu. Verta paminèti, jog siurrealizmas sulaukè didelio susidomèjimo Japonijoje. Takiguchi Shūzō, japonu poetas ir meno kritikas, buvęs pagrindine siurrealizmo figūra iki ir po Antrojo pasaulinio karo, ankoku butõ šokio teatrą suvokè kaip išskirtinai siurrealistinę meno formą.

11 Avandardo kultūrą galime apibūdinti kaip „praeities atmetimą ir opoziciją tradicijai" (Goodman 2006: 250).

12 Juliette T. Crump trisdešimt metų tyrinëja butõ, yra mačiusi daugiau nei penkiasdešimt pasirodymų Japonijoje, Šiaurès Amerikoje ir Europoje, pati dalyvavusi atliekant butõ.

13 Bodhisattva Kannon - viena labiausiai garbinamų budizme gailestingumo deivè. Dalai Lama laikomas šios deivès inkarnacija.

${ }^{14}$ Kazuo Ohno ir Tatsumi Hijikata glaudžiai bendradarbiavo nuo pat butõ atsiradimo $1959 \mathrm{~m}$. daugiau nei du dešimtmečius.

15 Vienas mitinio kūrimo akto pavyzdžių: pradžioje yra sèkla, embrionas ar ameba, atitinkanti amorfišką, uždaryta, sustingusi kūną, iš kurio centro pradeda skleistis augalas, pamažu atitirpsta visas kūnas, apsipila žiedais, pasiekia brandą ir pradeda nykti, vysti, džiūti, kol galiausiai apmiršta, vèl stoja žiema.

16 Sakurako San yra choreografė, butõ meistrè, pirmosios butõ šokio teatro trupès Lietuvoje ¡ikūrèja. 